\title{
Heavy Metal Uptake Responses in Plants Grown on Crude Oil-Polluted Soils as Prospects for Phytoremediation
}

\section{${ }^{1 *}$ OLAWEPO, GK; ${ }^{1}$ OGUNKUNLE, CO; ${ }^{1}$ FATOBA, PO; ${ }^{1}$ ANIMASAUN, DA; ${ }^{2}$ BEN- UWABOR, PO; ${ }^{3}$ DANZAKI, MM}

\author{
${ }^{*}$ Department of Plant Biology, University of Ilorin, Nigeria. ${ }^{2}$ Department of Natural and Environmental Sciences, Crown-Hill University, \\ Kwara State, Nigeria. ${ }^{3}$ Nigerian Army University, Biu, Borno State, Nigeria \\ *Corresponding Author Email: okg4eva@yahoo.com
}

\begin{abstract}
The demand and utilization of petroleum products have re-energized its exploration and exploitation globally and this upsurge in world production, refining and distribution of petroleum products have brought with it various problems of environmental pollution, which have effects on the ecosystems. Twenty (24) polyethylene pots each containing $7 \mathrm{~kg}$ of sandy loam soil mixed with $50 \mathrm{ml}$ of crude oil, were arranged in the Botanical garden of the University of Ilorin, Nigeria, to assess their ability to phytoextract heavy metals in Crude oil-polluted soil. Seeds of Amaranthus hybridus L., Tithonia diversifolia, Abelmoschus esculentus L. and Zea mays were sown in polyethylene containers containing $7 \mathrm{~kg}$ of contaminated or Control soil. The containers were arranged in a complete randomized design. Plants were left to grow for two months with regular watering. Plants were harvested, separated into roots and shoots and oven-dried to constant weight. The experimental plants have been able to reduce the concentration of $\mathrm{Cu}$ in both soils by about $45 \%$ to $85 \%, \mathrm{Cr}$ in the soil by $92.08 \%$ to $96.72 \%$, as the residual concentration varied between $66.00 \mathrm{mg} / \mathrm{kg}$ and $99.00 \mathrm{mg} / \mathrm{kg}$, Cd in the soil was reduced to $4.00 \mathrm{mg} / \mathrm{kg}$ and $17 \mathrm{mg} / \mathrm{kg}$ which represented $96.8 \%$ and $86.4 \%$ reduction. Tithonia had the highest $\mathrm{Pb}$ reduction in crude oilpolluted soil. Ni concentration was reduced by $85.84 \%$ by Tithonia planted in crude oil-polluted soil, $94.59 \%$ by Amaranthus hybridus planted in Control soil. These show that all the test plants were good phytoextractors of the metals.
\end{abstract}

DOI: https://dx.doi.org/10.4314/jasem.v24i7.5

Copyright: Copyright $(\mathrm{C} 2020$ Olawepo et al. This is an open access article distributed under the Creative Commons Attribution License (CCL), which permits unrestricted use, distribution, and reproduction in any medium, provided the original work is properly cited.

Dates: Received: 05 May 2020; Revised: 25 June 2020; Accepted: 06 July 2020

Keywords: Heavy metals, phytoremediation, Amaranthus hybridus L., Tithonia diversifolia, Abelmoschus esculentus L, Zea mays

Phytoremediation is a novel plant-based remediation technology applied worldwide to soil, water and sediments polluted by inorganic or organic materials. It makes use of naturally occurring processes by which plants and microbial rhizosphere flora degrade and/or sequester pollutants. It is more economical than alternative mechanical and chemical methods of eliminating hazardous pollutants from soils (Bollag et al., 1994). Inorganic pollutants occur as natural elements in the earth crust or atmosphere, and anthropogenic activities such as mining, agriculture, traffic and industrial activities encourage their release into the environment, thereby causing toxicity (Nriagu, 1979). Inorganic pollutant cannot be degraded but can be phytoremediated through volatilization, phytostabilization or sequestration in harvestable plant part. Inorganic pollutants that can be phytoremediated include macronutrients like nitrates and phosphates (Nwoko et al., 2004) and trace elements such as $\mathrm{Cr}, \mathrm{Fe}, \mathrm{Zn}, \mathrm{Ni}, \mathrm{Mn}, \mathrm{Mo}$, and $\mathrm{Cu}$ (Lytle et al., 1998). Plant roots extract metal contaminants from soil, polluted water and waste water, and accumulate them in their root tissue. Plants' roots uptake both organic and inorganic pollutants (Sinha et al., 2004). The bioavailability of a given compound depends upon the lipophilicity and the soil or water conditions e.g. $\mathrm{pH}$ and clay content. Considerable amount of the contaminants may be translocated above ground through the xylem and accumulated in the shoots. The roots and shoots are collected and incinerated to decompose the contaminants (Sinha et al., 2004). The objective of this study was to determine and report the uptake of $\mathrm{Cu}$, $\mathrm{Cr}, \mathrm{Cd}, \mathrm{Pb}$ and $\mathrm{Ni}$ by Amaranthus hybridus L., Tithonia diversifolia, Abelmoschus esculentus L. and Zea mays grown on crude oil-polluted soils.

\section{MATERIALS AND METHODS}

The method of Ogunkunle et al. (2013) was adopted. The experiment was carried out in the Botanical garden of the University of Ilorin, Nigeria, with 24 polyethylene pots, each containing Seven (7) $\mathrm{kg}$ of 
sandy loam soil mixed with $50 \mathrm{ml}$ of crude oil. Twelve containers contained the crude oil-polluted soil while the remaining twelve containers contained the Control soil. Seeds of Amaranthus hybridus L., Tithonia diversifolia, Abelmoschus esculentus L. and Zea mays were sown in polyethylene containers containing $7 \mathrm{~kg}$ of contaminated or Control soil.

The seeds were sown after two weeks of spiking the soil with crude oil. Six containers per treatment were used for each plant species. The containers were arranged in a complete randomized design (CRD). Two weeks after planting, plants were thinned to four seedlings per container. Plants were left to grow for two months with regular watering with borehole water under natural photoperiod and ambient conditions. After two months, plants were harvested, separated into roots and shoots (stem and leaves together), and washed with tap water to remove soil particles. Plant samples were properly labelled and oven-dried to constant weight at $80^{\circ} \mathrm{C}$.

Elemental analyses of soil samples: Analyses of the elemental contents of the soil, shoots and roots samples were determined with the adopted method of Abdulkadir et al. (2012). The air dried soil samples from each of the treatment were crushed, ground and powdered with a mortar and pestle. Each powdered soil sample $(0.1 \mathrm{~g})$ was carefully weighed into a test tube and a mixture of $0.5 \mathrm{ml}$ Trioxo-nitrate $\mathrm{V}$ acid $\left(\mathrm{HNO}_{3}\right), 1.5 \mathrm{ml}$ Perchloric acid $\left(\mathrm{HClO}_{4}\right)$ and $0.5 \mathrm{ml}$ hydrofluoric acid (HF) were added to each sample. The content was heated on a hot plate in a fume cupboard till colourless solution was formed. After cooling, the residue were transferred into $50 \mathrm{ml}$ beaker and made to volume up to $10 \mathrm{ml}$ with deionized distilled water. The digested samples were then analyzed for their various heavy metals $(\mathrm{Cu}, \mathrm{Cr}, \mathrm{Cd}$, $\mathrm{Pb}$ and $\mathrm{Ni}$ ) by using Atomic Absorption Spectrophotometry (AAS).

Elemental analyses of plant (root and shoot): Plant samples i.e., roots and shoots (stem and leaves) were crushed, ground and powdered separately with the help of a mortar and pestle. An amount of $0.1 \mathrm{~g}$ of each powdered plant sample was carefully weighed into a test tube and a mixture of $0.5 \mathrm{ml} 70 \%$ Perchloric acid $\left(\mathrm{HClO}_{4}\right), 2.5 \mathrm{ml}$ Trioxo-nitrate $(\mathrm{V})$ acid $\left(\mathrm{HNO}_{3}\right)$ and $0.5 \mathrm{ml}$ Tetraoxo-sulphate (VI) acid $\left(\mathrm{H}_{2} \mathrm{SO}_{4}\right)$ were added to each sample. The content was heated on a hot plate in a fume cupboard till the appearance of a clear solution. It was then set aside to cool. The residue was transferred into $50 \mathrm{ml}$ beaker and made to the volume, up to $10 \mathrm{ml}$ with deionized distilled water. The digested samples were then analyzed for their various heavy metals $(\mathrm{Cu}, \mathrm{Cr}, \mathrm{Cd}, \mathrm{Pb}$ and $\mathrm{Ni})$ by using Atomic Absorption Spectrophotometry (AAS).

Data Analyses: The data collected from the study were statistically analyzed with the use of SPSS. The means of the treatments were compared statistically with ANOVA, and the means separated using Duncan's Multiple Range Test (DMRT). Graphs were plotted using Origin 7.0 software.

\section{RESULTS AND DISCUSSIONS}

The tables below shows the concentrations of $\mathrm{Cu}, \mathrm{Cr}$, $\mathrm{Cd}, \mathrm{Pb}$ and $\mathrm{Ni}$ detected in the shoots, roots and soils used for the experiment. In shoots of plants, the mean $\mathrm{Cu}$ concentration was highest $(18.00 \pm 0.00 \mathrm{mg} / \mathrm{kg})$ in Amaranthus hybridus planted in crude oil-polluted soil and lowest $(4.00 \pm 1.00 \mathrm{mg} / \mathrm{kg})$ in Abelmoschus esculentus planted in crude oil-polluted soil. However, when the means were compared statistically, $\mathrm{Cu}$ concentrations in shoots of Tithonia diversifolia, Zea mays, Abelmoscus esculentus and Amaranthus hybridus planted in crude oil-polluted and Control soils did not differ at $p \leq 0.05$. On the other hand, the mean concentration of $\mathrm{Cu}$ in the roots was maximum $(21.50 \pm 5.50 \mathrm{mg} / \mathrm{kg})$ in roots of Tithonia diversfolia planted in crude oil-polluted soil and minimum $(10.00 \pm 1.00 \mathrm{mg} / \mathrm{kg})$ in the root of Abelmoschus esculentus planted in crude oil-polluted soil.

When the means were compared, there existed no significant difference among the $\mathrm{Cu}$ concentrations in the roots of the four plants planted in both soil types at $\mathrm{p} \leq 0.05$. Furthermore, the initial concentration of $\mathrm{Cu}$ in the soil was $20 \mathrm{mg} / \mathrm{kg}$ while the residual $\mathrm{Cu}$ concentrations in the two soils varied between $3.00 \pm 1.00 \mathrm{mg} / \mathrm{kg}$ and $11.00 \pm 0.00 \mathrm{mg} / \mathrm{kg}$ which were recorded in Tithonia diversfolia and Zea mays planted in crude oil-polluted soil and Zea mays planted in Control soil respectively. In general, the experimental plants have been able to reduce the concentration of $\mathrm{Cu}$ in both soils by about $45 \%(11.00 \mathrm{mg} / \mathrm{kg})$ to $85 \%$ $(3.00 \mathrm{mg} / \mathrm{kg})$.

Copper $(\mathrm{Cu})$ is an important element for plants and animals. Excessive concentrations of this metal are considered to be highly toxic. Roots and shoot of the plants contained comparable $\mathrm{Cu}$ concentrations. $\mathrm{Cu}$ concentrations in plants above $10-30 \mu \mathrm{g} / \mathrm{g}$ are regarded as poisonous (Macnicol and Beckett, 1985). Within roots, $\mathrm{Cu}$ is associated mainly with cell walls and is largely immobile. However, higher concentrations of $\mathrm{Cu}$ in shoots are always in phases of intensive growth and at the luxury $\mathrm{Cu}$ supply level (Tiffin, 1977). Relatively high concentrations of $\mathrm{Cu}$ in the Tithonia diversifolia and Zea mays in relatively high $\mathrm{pH}$ soil may be attributed to their biomass. This is in 
agreement with the findings of Weis and Weis (2004) who reported that at higher $\mathrm{pH}$ conditions greater than 7.0 enhanced $\mathrm{Cu}$ uptake. The permissible limit of copper for plants is $10 \mathrm{mg} / \mathrm{kg}$ recommended by WHO (Zigham et al., 2012). The maximum permissible limit of $\mathrm{Cu}$ according to SEPA of China is $100 \mathrm{mg} / \mathrm{kg}$. In some of the plant samples, concentration of copper was recorded above the permissible limit. In the soil samples, concentration of $\mathrm{Cu}$ was recorded above the recommended maximum level $(100 \mathrm{ug} / \mathrm{g})$ Chiroma et al. (2012). The present study classifies Tithonia diversifolia, Abelmoschus esculentus, Amaranthus hybridus and Zea mays as $\mathrm{Cu}$ accumulators having met the criteria for appraising the potential and efficiency of plants, which are their Remediation Factors and Phytoextraction Potentials. The mean concentration of $\mathrm{Cu}$ in the roots was highest $(21.50 \pm 5.50 \mathrm{mg} / \mathrm{kg})$ in roots of Tithonia diversfolia planted in crude oilpolluted soil and lowest $(10.00 \pm 1.00 \mathrm{mg} / \mathrm{kg})$ in the root of Abelmoschus esculentus planted in crude oilpolluted soil. Wagh et al. (2013) pointed out that $\mathrm{Cu}$ content of most plant is generally between 2 and 20 $\mathrm{mg} / \mathrm{kg}$ in the plants as $\mathrm{Cu}$ strongly binds to soils it is very immobile and hence the plant roots are frequently higher in $\mathrm{Cu}$ concentration than other plant tissues. This could be why more $\mathrm{Cu}$ concentrations were found in the roots of the plants used for this study.

Table 1: Concentration of $\mathrm{Cu}$ in the soils and plants used for the experiment

\begin{tabular}{lllll}
\hline & $\begin{array}{l}\text { Amaranthus } \\
\text { hybridus }\end{array}$ & $\begin{array}{l}\text { Tithonia } \\
\text { diversifolia }\end{array}$ & $\begin{array}{l}\text { Abelmoschus } \\
\text { esculentus }\end{array}$ & Zea mays \\
\hline A & $20.00^{\mathrm{a}}$ & $20.00 \mathrm{a}$ & $20.00^{\mathrm{a}}$ & $20.00^{\mathrm{a}}$ \\
B & $7.50 \pm 3.53^{\mathrm{c}-\mathrm{f}}$ & $9.50 \pm 0.70^{\mathrm{b}-\mathrm{f}}$ & $8.00 \pm 0.00^{\mathrm{c}-\mathrm{f}}$ & $11.00 \pm 0.00^{\mathrm{b}-\mathrm{f}}$ \\
C & $4.00 \pm 1.41^{\mathrm{ef}}$ & $3.00 \pm 1.41^{\mathrm{f}}$ & $6.50 \pm 0.70^{\mathrm{ef}}$ & $3.00 \pm 0.00^{\mathrm{f}}$ \\
D & $18.00 \pm 0.00^{\mathrm{ab}}$ & $17.00 \pm 2.82^{\mathrm{abc}}$ & $4.00 \pm 0.00^{\mathrm{ef}}$ & $16.001 \pm 2.72^{\mathrm{a}-\mathrm{d}}$ \\
E & $12.00 \pm 5.65^{\mathrm{a}-\mathrm{f}}$ & $21.50 \pm 7.77^{\mathrm{a}}$ & $10.00 \pm 1.41^{\mathrm{b}-\mathrm{f}}$ & $12.00 \pm 2.82^{\mathrm{a}-\mathrm{f}}$ \\
F & $15.00 \pm 2.82^{\mathrm{a}-\mathrm{d}}$ & $10.00 \pm 1.41^{\mathrm{b}-\mathrm{f}}$ & $13.00 \pm 2.82^{\mathrm{a}-\mathrm{e}}$ & $14.00 \pm 4.24^{\mathrm{a}-\mathrm{d}}$ \\
G & $14.00 \pm 4.24^{\mathrm{a}-\mathrm{d}}$ & $15.50 \pm 4.94^{\mathrm{a}-\mathrm{d}}$ & $11.50 \pm 2.12^{\mathrm{b}-\mathrm{f}}$ & $10.50 \pm 0.70^{\mathrm{b}-\mathrm{f}}$ \\
\hline
\end{tabular}

Values represent mean \pm standard deviation. Values with the same letter along the column are not significantly different at $p \leq 0.05$. Key: $A=$ Initial concentration of metal in the soil; $B=$ Residual concentration of metal in the Control soil; $C=R e s i d u a l$ concentration of metal in the Crude oil-polluted soil; $D=$ Metal concentration in the shoots of plants in Crude oil-polluted soil; $E=M e t a l$ concentration in the roots of plants in Crude oil-polluted soil; $F=$ Metal concentration in the shoot of plants in Control soil; $G=M e t a l$ concentration in the root of plants in Control soil

The heavy metals' uptake responses of experimental plants grown in crude oil polluted and Control soils are shown in Table 2. The concentration of $\mathrm{Cr}$ in shoot was highest in the shoot of Abelmoschus esculentus $(97.00 \pm 48.00 \mathrm{mg} / \mathrm{kg})$ and lowest in shoot of Zea mays $(15.00 \pm 0.00 \mathrm{mg} / \mathrm{kg})$ planted in Control soil. When the mean values were compared, the $\mathrm{Cr}$ concentrations were found to be statistically the same for all experimental plants at $\mathrm{p} \leq 0.05$.

The concentration of $\mathrm{Cr}$ in root was highest in Amaranthus hybridus $(117.00 \pm 18.00 \mathrm{mg} / \mathrm{kg})$ followed by Tithonia diversifolia $(88.00 \pm 11.00 \mathrm{mg} / \mathrm{kg})$ and lowest $(12 \pm 0.00 \mathrm{mg} / \mathrm{kg})$ in Zea mays. When the means were compared, Amaranthus hybridus planted in crude oil-polluted soil had the highest concentration of $\mathrm{Cr}$, but not significantly greater than Zea mays and Tithonia diversifolia planted in crude oil-polluted soil at $\mathrm{p} \leq 0.05$. The least $\mathrm{Cr}$ concentration was observed in Zea mays $(12.00 \mathrm{mg} / \mathrm{kg})$ planted in Control soil.

The experimental plants were able to reduce the initial concentration of $\mathrm{Cr}$ in the soil $(1250 \mathrm{mg} / \mathrm{kg})$ by $92.08 \%$ to $96.72 \%$, as the residual concentration varied between $66.00 \mathrm{mg} / \mathrm{kg}$ (crude oil-polluted soil of Abelmoschus esculentus) and $99.00 \mathrm{mg} / \mathrm{kg}$ (crude oilpolluted soil of Zea mays). This shows that all the test plants are good.
Chromium ( $\mathrm{Cr}$ ) is a non-essential metal to plant growth, and may be possible that plants do not have any specific mechanism for transport of $\mathrm{Cr}$ (Shanker et al., 2005). The soil used for this study had high concentrations of $\mathrm{Cr}$. Results from the present study showed that all plant parts contained statistically the same $\mathrm{Cr}$ concentration. This is in contrast to assertion by Khairia (2012) who stated that $\mathrm{Cr}$ is immobilized in the vacuoles of the root cells and showed less translocation, thus rendering it less toxic. This may be a neutral toxicity response of the plants (Macnicol and Bekett, 1985). According to Macnicol and Bekett (1985), the toxic levels of $\mathrm{Cr}$ in plants range from 1 to $10 \mu \mathrm{g} / \mathrm{g}$ dry weight. The permissible limit of Chromium for plants is $1.30 \mathrm{mg} / \mathrm{kg}$ recommended by WHO.The maximum permissible limit of $\mathrm{Cr}$ according to SEPA of China is $250 \mathrm{mg} / \mathrm{kg}$. In plant, all the partscontained chromium concentrations that were above the permissible limit. This could be because of the availability of $\mathrm{Cr}$ in large concentrations in the soil and the $\mathrm{pH}$ of the soil. The concentration of lead in the pretreated soil was above the recommended maximum level $(100 \mathrm{ug} / \mathrm{g})$ according to WHO (Chiroma et al., 2012). The present study classifies Tithonia diversifolia, Abelmoschus esculentus, Amaranthus hybridus and Zea maysas $\mathrm{Cr}$ accumulators having met the criteria for appraising the potential and efficiency of plants. 
Table 2: Concentration of $\mathrm{Cr}$ in the soils and plants used for the experiment

\begin{tabular}{lllll}
\hline & $\begin{array}{l}\text { Amaranthus } \\
\text { hybridus }\end{array}$ & $\begin{array}{l}\text { Tithonia } \\
\text { diversifolia }\end{array}$ & $\begin{array}{l}\text { Abelmoschus } \\
\text { esculentus }\end{array}$ & Zea mays \\
\hline A & $1250.00^{\mathrm{a}}$ & $1250.00^{\mathrm{a}}$ & $1250.00^{\mathrm{a}}$ & $1250.00^{\mathrm{a}}$ \\
$\mathrm{B}$ & $83.00 \pm 21.21^{\mathrm{bcd}}$ & $67.50 \pm 2.12^{\text {cde }}$ & $52.50 \pm 34.64^{\text {cde }}$ & $68.00 \pm 2.82^{\mathrm{bc}}$ \\
$\mathrm{C}$ & $89.00 \pm 15.55^{\mathrm{b}-\mathrm{e}}$ & $55.50 \pm 7.77^{\mathrm{c}-\mathrm{g}}$ & $66.00 \pm 0.00^{\mathrm{c}-\mathrm{g}}$ & $99.00 \pm 18.38^{\text {cde }}$ \\
D & $78.50 \pm 14.84^{\mathrm{b}-\mathrm{e}}$ & $88.00 \pm 15.55^{\mathrm{bcd}}$ & $97.00 \pm 67.88^{\mathrm{bc}}$ & $70.50 \pm 0.70^{\mathrm{b}-\mathrm{e}}$ \\
E & $117.00 \pm 25.45^{\mathrm{b}}$ & $85.50 \pm 19.09^{\mathrm{b}-\mathrm{e}}$ & $60.50 \pm 2.12^{\mathrm{c}-\mathrm{f}}$ & $83.00 \pm 7.07^{\mathrm{b}-\mathrm{e}}$ \\
F & $53.00 \pm 1.41^{\mathrm{c}-\mathrm{g}}$ & $42.00 \pm 9.89^{\mathrm{d}-\mathrm{g}}$ & $71.50 \pm 2.12^{\mathrm{b}-\mathrm{e}}$ & $15.00 \pm 0.00^{\mathrm{fg}}$ \\
G & $52.00 \pm 14.14^{\mathrm{c}-\mathrm{g}}$ & $42.50 \pm 2.12^{\mathrm{d}-\mathrm{g}}$ & $37.50 \pm 28.99^{\mathrm{e}-\mathrm{g}}$ & $12.00 \pm 0.00^{\mathrm{g}}$ \\
\hline
\end{tabular}

Values represent mean \pm standard deviation. Values with the same letter along the column are not significantly different at $p \leq 0.05$.

Concentrations of $\mathrm{Cd}(\mathrm{mg} / \mathrm{kg})$ in crude oil-polluted and Control soils and plants are shown in Table 3 . The least $\mathrm{Cd}$ concentration $(0.5 \pm 0.50 \mathrm{mg} / \mathrm{kg})$ was found in the shoot of Tithonia diversifolia planted in crude oilpolluted soil while the highest concentration $(13.50 \pm 0.50 \mathrm{mg} / \mathrm{kg})$ was found in the shoot of Tithonia diversifolia planted in Control soil. However, there was no statistical difference in the concentrations of $\mathrm{Cd}$ in the shoots of other test plants when compared with that found in the shoot of Tithonia diversifolia planted in natural soil except for Tithonia diversifolia planted in crude oil-polluted soil. Conversely, the concentration of $\mathrm{Cd}$ in the roots showed that Abelmoschus esculentus $(23.50 \pm 1.50 \mathrm{mg} / \mathrm{kg})$ and Zea mays $(20.00 \pm 2.00 \mathrm{mg} / \mathrm{kg})$ planted in Control soil had the highest $\mathrm{Cd}$ concentrations. The lowest concentrations of $\mathrm{Cd}$ were found in the roots of Tithonia diversifolia and Abelmoschus esculentus planted in crude oil-polluted soil but their means were statistically the same with the root of Zea mays in crude oil-polluted soil and Amaranthus hybridus planted in both soils. At the same time, initial concentration of $\mathrm{Cd}$ in the soil was $125 \mathrm{mg} / \mathrm{kg}$ and this was reduced to residual concentrations that varied between $4.00 \mathrm{mg} / \mathrm{kg}$ and $17 \mathrm{mg} / \mathrm{kg}$ which represented $96.8 \%$ and $86.4 \%$ reduction. The test plants were able to reduce $\mathrm{Cd}$ both in crude oil polluted and Control soils hence are good phytoextractors of $\mathrm{Cd}$.

The present study classifies Tithonia diversifolia, Abelmoschus esculentus, Amaranthus hybridus and Zea mays as cadmium accumulators. These species were able to phytoextract $\mathrm{Cd}$ above the permissible level. This could be because of the organic matter content of the soil and acidic nature of the soil.The permissible limit of Cadmium in plants, recommended by $\mathrm{WHO}$ is $0.02 \mathrm{mg} / \mathrm{kg}$. The maximum permissible limit of $\mathrm{Cd}$ in the soil according to SEPA of China is $0.6 \mathrm{mg} / \mathrm{kg}$. The concentration of cadmium in the soil sample used was above maximum permissible limit (MPL) (0.6 mg/Kg) (SEPA, 1995). Voogt et. al., (1980) upheld that Cd can be taken up by plant such as maize, spinach, wheat and rice. It is capable of accumulating in food chains and its uptake is irrevocable and its excretion is very slow, it is therefore very toxic in nature. Uba et al. (2008) in their assessment of heavy metals bioavailability discovered that extractable Cadmium was found to be above the critical permissible concentration of $3.0 \mathrm{mg} / \mathrm{kg}$. The findings in this study corroborated the work of Egberongbe (2010) who reported that Tithonia diversifolia seedlings absorbed $\mathrm{Cd}$ and $\mathrm{Pb}$ in polluted soils, and the contents in the root were more than the contents in the shoot.

\begin{tabular}{|c|c|c|c|c|}
\hline & $\begin{array}{l}\text { Amaranthus } \\
\text { hybridus }\end{array}$ & $\begin{array}{l}\text { Tithonia } \\
\text { diversifolia }\end{array}$ & $\begin{array}{l}\text { Abelmoschus } \\
\text { esculentus }\end{array}$ & Zea mays \\
\hline $\mathrm{A}$ & $125.00^{\mathrm{a}}$ & $125.00^{\mathrm{a}}$ & $125.00^{\mathrm{a}}$ & $125.00^{\mathrm{a}}$ \\
\hline B & $4.00 \pm 1.41^{\mathrm{f}-\mathrm{l}}$ & $10.00 \pm 1.41^{\mathrm{d}-\mathrm{g}}$ & $10.00 \pm 0.00^{\mathrm{d}-\mathrm{g}}$ & $9.00 \pm 0.00^{\mathrm{d}-\mathrm{h}}$ \\
\hline $\mathrm{C}$ & $17.00 \pm 0.00^{\text {bcd }}$ & $12.00 \pm 5.65^{\text {def }}$ & $17.00 \pm 5.65^{\text {bcd }}$ & $6.50 \pm 9.19^{\mathrm{e}-\mathrm{i}}$ \\
\hline D & $8.50 \pm 0.70^{\mathrm{e}-1}$ & $0.50 \pm 0.70^{\mathrm{i}}$ & $9.00 \pm 1.41^{\mathrm{d}-\mathrm{h}}$ & $3.00 \pm 1.41^{\text {ghi }}$ \\
\hline E & $6.50 \pm 0.70^{\mathrm{e}-1}$ & $1.00 \pm 0.00^{\mathrm{hi}}$ & $0.50 \pm 0.70^{\mathrm{i}}$ & $3.50 \pm 4.94^{\mathrm{ghi}}$ \\
\hline $\mathrm{F}$ & $4.50 \pm 4.94^{\mathrm{f}-1}$ & $13.50 \pm 0.70^{\text {cde }}$ & $5.00 \pm 2.82^{\mathrm{f}-\mathrm{i}}$ & $6.50 \pm 2.12^{\mathrm{e}-\mathrm{i}}$ \\
\hline $\mathrm{G}$ & $5.50 \pm 4.94^{\mathrm{e}-\mathrm{I}}$ & $13.50 \pm 4.94^{\text {cde }}$ & $23.50 \pm 2.12^{\mathrm{b}}$ & $20.00 \pm 2.82^{\mathrm{bc}}$ \\
\hline
\end{tabular}

Values represent mean \pm standard deviation. Values with the same letter along the column are not significantly different at $\mathrm{p} \leq 0.05$.

Table 4 shows the uptake responses of Tithonia diversifolia, Zea mays, Abelmoschus esculentus and Amaranthus hybridus to $\mathrm{Pb}$ in crude oil-polluted and Control soils. $\mathrm{Pb}$ concentration was maximum at $109.00 \pm 3.00 \mathrm{mg} / \mathrm{kg}$ in the shoots of $T$. diversifolia planted in crude oil-polluted soil and minimum $(25.50 \pm 5.50 \mathrm{mg} / \mathrm{kg})$ in the shoot of $Z$. mays planted in Control soil. However, all the experimental plants planted in crude oil-polluted soil had statistically the same $\mathrm{Pb}$ concentration in their shoots.

The concentration of $\mathrm{Pb}$ in the roots of the test plants was statistically higher in the roots of Tithonia diversifolia, Zea mays, and Abelmoschus esculentus planted in Control soil. 
The range of $\mathrm{Pb}$ concentration in the roots of the plants was found to be from $116 \pm 5.00 \mathrm{mg} / \mathrm{kg}$ (in Amaranthus hybridus planted in Control soil) to $27.50 \pm 0.50 \mathrm{mg} / \mathrm{kg}$ (in Zea mays planted in Control soil). Furthermore, by the interaction of the roots of the plants with the polluted soils, the initial concentration of $\mathrm{Pb}$ in the soil was $625 \mathrm{mg} / \mathrm{kg}$ and this had been reduced by each plant to between $39.00 \pm 13.00 \mathrm{mg} / \mathrm{kg}$ to $69.00 \pm 8.00$ $\mathrm{mg} / \mathrm{kg}$ which represented $93.76 \%$ and $88.96 \%$ reduction respectively. Tithonia had the highest $\mathrm{Pb}$ reduction in crude oil-polluted soil followed by Abelmoschus esculentus in crude oil-polluted soil which was the same statistically $(\mathrm{p} \leq 0.05)$ with that of Zea mays in Control soil. Generally, the experimental plants were able to reduce the concentration of $\mathrm{Pb}$ in the soil. Lead $(\mathrm{Pb})$ is not essential and also toxic to plants. $\mathrm{Pb}$ is believed to be the metal of least bioavailability and the most highly accumulated metal in root tissue while $\mathrm{Pb}$ shoot accumulation is much lower in most plant species (Kabata-Pendias, 2001). This is not in agreement with the results obtained from the plants used in this study as there was no significant difference in the $\mathrm{Pb}$ concentration obtained in the root and shoot of the plant species. This may be as a result of the $\mathrm{pH}$ or the difference in the nature of the soils used. $\mathrm{Pb}$ translocation and uptake studies showed that $\mathrm{Pb}$ is mobile within the plant under certain conditions such as the nature of the plant (Meers et al., 2005). Moreover, Blaylock and Huang (2000) reported that shoot $\mathrm{Pb}$ concentrations reached a value similar to the concentration found in intact roots of the same species, when it is immersed in a nutrient solution containing $\mathrm{Pb}$. John (2013) observed the $\mathrm{Pb}$ concentrations of the sunflower and mustard. $\mathrm{The} \mathrm{Pb}$ and $\mathrm{Cd}$ concentrations in the shoots compared to the roots were about $54 \%$ and $30 \%$ respectively. He attributed this to the high insolubility of $\mathrm{Pb}$ and that it tends to form highly stable adsorption complexes. John (2013) reported that Helianthus annuus (Sunflowers) had shoot $\mathrm{Pb}$ concentrations to be $60 \mathrm{mg} / \mathrm{kg}$ while Brassica juncea (Indian mustard) plants had $35 \mathrm{mg} / \mathrm{kg}$, and the average dry weight for sunflowers was $0.60 \mathrm{~g}$, while mustard dry weight was $0.40 \mathrm{~g}$ and obtained no significant differences in dry weight between treatments used. The concentration of $\mathrm{Pb}$ obtained in his work is similar to those obtained in this study.

Table 4: Concentration of $\mathrm{Pb}$ in the soils and plants used for the experiment

\begin{tabular}{lllll}
\hline & $\begin{array}{l}\text { Amaranthus } \\
\text { hybridus }\end{array}$ & $\begin{array}{l}\text { Tithonia } \\
\text { diversifolia }\end{array}$ & $\begin{array}{l}\text { Abelmoschus } \\
\text { esculentus }\end{array}$ & Zea mays \\
\hline $\mathrm{A}$ & $625.00^{\mathrm{a}}$ & $625.00^{\mathrm{a}}$ & $625.00^{\mathrm{a}}$ & $625.00^{\mathrm{a}}$ \\
$\mathrm{B}$ & $40.50 \pm 0.70^{\mathrm{ijk}}$ & $47.50 \pm 2.12^{\mathrm{h}-\mathrm{k}}$ & $40.00 \pm 0.00^{\mathrm{ijk}}$ & $40.00 \pm 0.00^{\mathrm{ijk}}$ \\
$\mathrm{C}$ & $69.00 \pm 11.31^{\mathrm{f}-\mathrm{h}}$ & $39.00 \pm 18.38^{\mathrm{jk}}$ & $67.50 \pm 6.36^{\mathrm{fgh}}$ & $62.00 \pm 5.65^{\mathrm{g}-\mathrm{j}}$ \\
$\mathrm{D}$ & $66.50 \pm 7.77^{\mathrm{f}-\mathrm{g}}$ & $109.00 \pm 4.24^{\mathrm{bc}}$ & $93.50 \pm 17.67^{\mathrm{d}-\mathrm{f}}$ & $99.00 \pm 1.41^{\mathrm{b}-\mathrm{e}}$ \\
$\mathrm{E}$ & $38.00 \pm 9.89^{\mathrm{j}-\mathrm{k}}$ & $104.50 \pm 4.94^{\mathrm{bcd}}$ & $99.50 \pm 12.02^{\mathrm{b}-\mathrm{e}}$ & $102.50 \pm 6.36^{\mathrm{bcd}}$ \\
$\mathrm{F}$ & $98.00 \pm 2.82^{\mathrm{b}-\mathrm{e}}$ & $73.50 \pm 10.60^{\mathrm{c}-\mathrm{h}}$ & $79.00 \pm 15.55^{\mathrm{d}-\mathrm{g}}$ & $25.50 \pm 7.77^{\mathrm{k}}$ \\
$\mathrm{G}$ & $116.00 \pm 7.07^{\mathrm{b}}$ & $78.50 \pm 9.19^{\mathrm{d}-\mathrm{g}}$ & $86.00 \pm 36.76^{\mathrm{c}-\mathrm{g}}$ & $27.50 \pm 0.70^{\mathrm{k}}$ \\
\hline
\end{tabular}

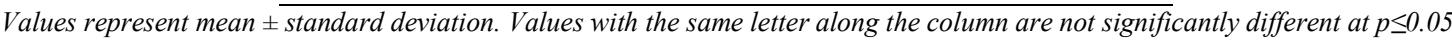

The residual concentration of $\mathrm{Ni}$ in the shoots and roots of the experimental plants and crude oil-polluted and Control soil are shown in Table 5. The concentrations of $\mathrm{Ni}$ in the shoots varied from $30.00 \pm 30.50 \mathrm{mg} / \mathrm{kg}$ to $114.50 \pm 8.50 \mathrm{mg} / \mathrm{kg}$. The highest concentration numerically, was found in Tithonia diversifolia planted in crude oil-polluted soil while the lowest was found in shoot of Abelmoschus esculentus planted in Control soil. Statistically, there was no significant difference in the concentrations of $\mathrm{Ni}$ in the selected plants at $\mathrm{p} \leq 0.05$. Also in the roots of the selected plants, $\mathrm{Ni}$ was highest in $T$. diversifolia planted in crude oil-polluted soil followed by Zea mays planted in crude oil-polluted soil. The residual concentration of $\mathrm{Ni}$ was highest $(150.50 \mathrm{mg} / \mathrm{kg})$ in Tithonia diversifolia planted in crude oil-polluted soil and lowest in Control soil of Amaranthus hybridus $(57.50 \mathrm{mg} / \mathrm{kg})$. The initial soil $\mathrm{Ni}$ concentration of $1062.5 \mathrm{mg} / \mathrm{kg}$ was reduced by the plants by $85.84 \%$ (by Tithonia diversifolia planted in crude oil-polluted soil) to $94.59 \%$ (by Amaranthus hybridus planted in Control soil). In general, the selected plants were able to reduce the level of $\mathrm{Ni}$ significantly in the polluted soils. Nickel (Ni) has been considered to be an essential trace element for human and animal health (Khairia, 2012). Prasad (2004) in his work observed that Nickel concentration in non-polluted soils to be between $5-50 \mathrm{mg} / \mathrm{kg}$, and the plants between $0.4-3$ $\mathrm{mg} / \mathrm{kg}$. The permissible limit of Nickel in plants, recommended by $\mathrm{WHO}$, is $10 \mathrm{mg} / \mathrm{kg}$. The maximum permissible limit of $\mathrm{Ni}$ according to SEPA of China is $60 \mathrm{mg} / \mathrm{kg}$. The concentration of Nickel in pretreated soil was above maximum permissible limit by SEPA (1995) i.e. $60 \mathrm{mg} / \mathrm{kg}$. Chen and Cutright (2001) reported that sunflower (Asteraceae) can also be utilized for the removal of $\mathrm{Cd}, \mathrm{Cr}$, and $\mathrm{Ni}$ in polluted soil. The present study classifies Tithonia diversifolia, Abelmoschus esculentus, Amaranthus hybridus and Zea mays as $\mathrm{Ni}$ accumulators. The least $\mathrm{Cd}$ concentration $(0.5 \pm 0.50 \mathrm{mg} / \mathrm{kg})$ was found in the shoot of Tithonia diversifolia planted in crude oil-polluted soil while the highest concentration (13.50 \pm 0.50 $\mathrm{mg} / \mathrm{kg}$ ) was found in the shoot of Tithonia diversifolia planted in Control soil. 
Table 5: Concentration of $\mathrm{Ni}$ in the soils and plants used for the experiment

\begin{tabular}{lllll}
\hline & $\begin{array}{l}\text { Amaranthus } \\
\text { hybridus }\end{array}$ & $\begin{array}{l}\text { Tithonia } \\
\text { diversifolia }\end{array}$ & $\begin{array}{l}\text { Abelmoschus } \\
\text { esculentus }\end{array}$ & Zea mays \\
\hline A & $1062.50^{\mathrm{a}}$ & $1062.50^{\mathrm{a}}$ & $1062.50^{\mathrm{a}}$ & $1062.50^{\mathrm{a}}$ \\
$\mathrm{B}$ & $57.50 \pm 9.19^{\mathrm{f}-\mathrm{g}}$ & $78.50 \pm 2.12^{\mathrm{c}-\mathrm{g}}$ & $66.50 \pm 6.36^{\mathrm{c}-\mathrm{g}}$ & $67.00 \pm 1.41^{\mathrm{c}-\mathrm{g}}$ \\
$\mathrm{C}$ & $72.00 \pm 8.48^{\mathrm{c}-\mathrm{g}}$ & $150.50 \pm 0.70^{\mathrm{b}}$ & $83.50 \pm 9.19^{\mathrm{c}-\mathrm{g}}$ & $72.00 \pm 38.18^{\mathrm{c}-\mathrm{g}}$ \\
$\mathrm{D}$ & $51.00 \pm 14.14^{\mathrm{fg}}$ & $114.50 \pm 12.02^{\mathrm{b}-\mathrm{e}}$ & $61.50 \pm 14.84^{\mathrm{c}-\mathrm{g}}$ & $87.50 \pm 19.09^{\mathrm{c}-\mathrm{g}}$ \\
E & $58.50 \pm 24.74^{\mathrm{d}-\mathrm{g}}$ & $120.00 \pm 22.62^{\mathrm{bc}}$ & $63.50 \pm 3.53^{\mathrm{c}-\mathrm{g}}$ & $119.00 \pm 31.11^{\mathrm{bcd}}$ \\
F & $98.00 \pm 0.00^{\mathrm{b}-\mathrm{f}}$ & $37.50 \pm 2.12^{\mathrm{fg}}$ & $30.50 \pm 43.13^{\mathrm{g}}$ & $64.50 \pm 20.50^{\mathrm{c}-\mathrm{g}}$ \\
$\mathrm{G}$ & $60.00 \pm 84.85^{\mathrm{c}-\mathrm{g}}$ & $41.50 \pm 2.12^{\mathrm{fg}}$ & $88.00 \pm 0.00^{\mathrm{c}-\mathrm{g}}$ & $70.50 \pm 26.16^{\mathrm{c}-\mathrm{g}}$ \\
\hline
\end{tabular}

Values represent mean \pm standard deviation. Values with the same letter along the column are not significantly different at $p \leq 0.05$.

Conclusion: In this study, four plant species namely Tithonia diversifolia, Abelmoschus esculentus, Amaranthus hybridus and Zea mays against five heavy metals, namely copper $(\mathrm{Cu})$, lead $(\mathrm{Pb})$, chromium $(\mathrm{Cr})$, cadmium $(\mathrm{Cd})$ and nickel $(\mathrm{Ni})$ were evaluated based on the criteria stated. On the basis of the results gotten, the plants could be classified as accumulators of heavy metals.

\section{REFERENCES}

Abdulkadir, KA; Mojeed, OL; Oladele, JP (2012). Effect of mycorrhizal inoculation on the growth and Phytoextraction of heavy metals by maize grown inoil contaminated soil. Pak. J. Bot. 44(1): 221-230

Blaylock, MJ; Huang, JW (2000). Phytoextraction of metals. In I.Raskin and B.Ensley (Eds.), Phytoremediation of toxic metals, John Weily and Sons, New York, USA. pp. 53-70

Bollag, JM; Mertz, T; Otijen, L (1994). Role of microorganisms in soil remediation. In: Anderson T.A, Coats J.R. eds. Bioremediation through rhizosphere technology. ACS.Symp.Ser.563. Am. Chem.Soc. York, PA, Maple press. pp. 2-10

Chen, H; Cutright, T (2001). EDTA and HEDTA effects on $\mathrm{Cd}, \mathrm{Cr}$, and $\mathrm{Ni}$ uptake by Helianthus annuus. Chemosphere. 45: 21-28

Chiroma, TM; Ebewele, RO; Hymore, FK (2012). Levels of heavy metals $(\mathrm{Cu}, \mathrm{Zn}, \mathrm{Pb}, \mathrm{Fe}$ and $\mathrm{Cr})$ in Bushgreen and Roselle irrigated with treated and untreated urban sewage water. International Research Journal of Environment Sciences. 1(4):50-55

Egberongbe, RK; Awodoyin, RO; Ogunyemi, S (2010). Can Tithonia diversifolia (Hemsl.) A. Gray, A Pantropic invasive weed species, clean up spent lubricating oil polluted soil? Citadel Journal of Environmental Sciences. 9(1\&2): 71 79
John, B (2013). Impact of paired planting of sunflower (Helianthus annuus L.) and Indian mustard (Brassica juncea (L.) Czern.) on lead phytoextraction, Bachelor of Science in Environmental Science, Rubenstein School of Environment \& Natural Resources, University of Vermont.pp 1-13

Kabata-Pendias, A; Pendias, H (2001). Trace Elements in Soils and Plants. CRC Press, Boca Raton FL, USA

Khairia, MA (2012). Assessment of Heavy Metals Accumulation in Native Plant Species from Soils Contaminated in Riyadh City, Saudi Arabia.Life Science Journal. 9(2):384-392

Lytle, CM; Lytle, FW; Yang, N; Qian, JH; Hansen, D; Zayed, A; Terry, N (1998). Reduction of Cr(VI) to $\mathrm{Cr}$ (III) by Wetland Plants: Potential for in situ Heavy Metals Detoxification. Environ. Sci. Technol. 32:3087-3093

Macnicol, RD; Beckett, PHT (1985). Critical Tissue Concentrations of Potentially Toxic Elements. Plant Soil. 85: 107-114

Meers, E; Lamsal, S; Vervaeke, P; Hopgood, M; Lust, N; Tack, FMG (2005). Availability of Heavy Metals for Uptake by Salix viminalis on a Moderately Contaminated Dredged Sediment Disposal Site. Environ. Poll. 137: 354-364

Nriagu, JO (1979). Global inventory of natural and anthropogenic emissions of trace metals to the atmosphere. Nature, 279: 409-411

Nwoko, CO; Okeke, PN; Ac-Chukwuocha, N (2004). Preliminary studies on nutrient removal potential of selected aquatic plants. J. Discovery and Innovation. Afr. Acad. Sci. 16(3): 133-136

Ogunkunle, CO; Fatoba, PO; Awotoye, OO; Olorunmaiye, KS (2013).Root-shoot partitioning of copper, chromium and zinc in Lycopersicon esculentum and Amaranthus hybridus grown in 
cement-polluted soil. Environmental and Experimental Biology. 11: 131-136

SEPA (1995). Environmental quality standard for soils. State Environmental Protection Administration, China. GB15618

Shanker, AK; Cervantes, C; Loza-Tavera, H; Avudainayagam, S (2005). Chromium Toxicity in Plants. Environ. Intr. 31:739-753

Sinha, RK; Heart, S; Tandon, PK (2004). Phytoremediation: role of plants incontaminated site management, in Book of Environmental Bioremediation Technologies, pp. 315-330, Springer, Berlin, Germany

Tiffin, LO (1977). The Form and Distribution of Metals in Plants: An Overview. In Proc. Hanford Life Sciences Symp. U.S. Department of Energy, Symposium Series, Washington, D.C., pp.315
Uba, S; Uzazi, A; Henrison, GFS; Balarabe, ML; Okunola, OJ (2008). Assessment of Heavy Metals Bioavailability in Dumpsites in Zaria. Afr. $J$ Biotech. 7: 122-130

Voogt, DEP; Van, HB; Fermstra, JP; Copus, PJW (1980)., Exposure and Health Effect of Cadmium. Toxic. Environ. Chem. 3:89 - 109

Weis, JS; Weis, P (2004). Metal Uptake, Transport and Release by Wetland Plants: Implications for Phytoremediation and Restoration. Environ. Inter. 30:685-700

Zaigham, H; Zubair, A; Khalid, U; Khattak, MI; Rizwan, UK; Jabar, ZK (2012). Civic Pollution and Its Effect on Water Quality of River Toi at District Kohat, NWF. Res. J. Environ. Earth Sci. 4: 5 . 